\title{
Effects of Microwave Pretreatment on Mesophilic Anaerobic Digestion for Mixture of Primary and Secondary Sludges Compared with Thermal Pretreatment
}

\author{
Woon-Ji Park, Johng-Hwa Ahn ${ }^{\dagger}$ \\ Department of Environmental Engineering, College of Engineering, Kangwon National University, Chuncheon 200-701, Korea
}

\begin{abstract}
This work experimentally determined the effect of thermal and microwave pretreatments on the anaerobic digestion of mixtures of municipal primary and secondary sludges in semi-continuous mesophilic digesters at hydraulic retention times (HRT) of 20, 15, 10, 7 , and 5 days. The ratio of soluble chemical oxygen demand (COD) to total COD in thermally pretreated and microwaved sludges at $80^{\circ} \mathrm{C}$ was 2.7 and 3.2 times higher than that of raw sludge, respectively. The volatile solids (VS) and COD removal efficiencies in all three digesters fed with raw (control), thermally pretreated (TM), and microwaved (MW) sludges decreased as the HRT was reduced. The highest relative improvement in VS removal compared to the control occurred at the HRT of 5 days in the TM and MW $(29$ and $41 \%$ higher than the control, respectively). At this HRT, improvement in the COD removal efficiencies in the TM and MW compared to the control was 28 and 53\%, respectively. Improvements in biogas production compared with the control increased in both the TM and MW as the HRT was reduced to 5 days. The relative improvement in daily biogas production compared to the control from the TM and MW was 33 and $53 \%$ higher than the control at the HRT of 5 days, respectively. The results show that microwave pretreatment is more effective than thermal pretreatment in increasing the solubilization degree and mesophilic anaerobic biodegradability of sewage sludge.
\end{abstract}

Keywords: Biogas, Digester, Disintegration, Process, Sewage sludge

\section{Introduction}

Processing sewage sludge for disposal is one of the most important and complex problems in the operation of municipal wastewater treatment plants [1]. Anaerobic digestion has long been used to treat sludge generated by the treatment of municipal and industrial wastewater. Sludge consists mainly of bacterial materials that commonly withstand direct anaerobic degradation because bacterial cell walls form physical and chemical barriers to enzymatic degradation and hydrolysis of intracellular organic material from cells in the sludge [2]. As a consequence, $20-30 \%$ of the organic matter is mineralized in typical anaerobic digestion systems [3].

Anaerobic degradation of particulate materials and macromolecules occurs in four steps: hydrolysis, acidogenesis, acetogenesis, and methanogenesis. In sludge digestion, hydrolysis is the rate-limiting step [4]. During this process, bacteria release extracellular enzymes that break down and solubilize organic particulate matter, so that the particulates can be used as substrates in subsequent reactions. Therefore, to improve digestion efficiency, the most logical approach is to disrupt the bacterial or microbial cells in the sludge.
Disruption of bacteria in sludge may be performed mechanically, ultrasonically, chemically, or thermally [5]. Mechanical pretreatment is highly effective but is complicated and expensive [1]. Sonication can disrupt $70-100 \%$ of sludge cells, but this approach is energy-intensive [1]. Chemical and thermochemical pretreatments are efficient [6], but they require extreme reaction conditions and commonly require the use of specialized materials. Thermal treatment prior to anaerobic digestion has been examined as a possible approach [1]. Conventional lowtemperature thermal treatment requires a longer contact time than high-temperature treatment [7]. The high costs of wet sludge disintegration, in addition to corrosion problems and limited knowledge of the process itself, prevent this approach from achieving its potential as an anaerobic process [1]. Consequently, an effective and economical pretreatment method is essential. One possible approach is to use microwave irradiation.

Industrial use of microwave heating as an alternative to conventional heating in chemical reactions is becoming popular mainly due to a dramatic reduction in reaction times [8]. Microwaves are used in many applications, including the decomposition of organic materials, sterilization of medical waste, and inactivation of microorganisms [9]. The advantages of micro- (c) This is an Open Access article distributed under the terms of the Creative Commons Attribution Non-Commercial License (http://creativecommons. org/licenses/by-nc/3.0/) which permits unrestricted non-commercial use, distribution, and reproduction in any medium, provided the original work is properly cited.
Received January 18, 2010 Accepted May 31, 2011

${ }^{\dagger}$ Corresponding Author

E-mail: johnghwa@kangwon.ac.kr

Tel: +82-33-250-6357 Fax: +82-33-254-6357 
waves in these applications include rapid heating, pathogen destruction, ease of control, and compactness of the microwave generator [10]. Destruction of microorganisms is generally thought to occur due to the thermal effects of microwave exposure, although several researchers have investigated whether or not such irradiation also has a non-thermal effect [11]. The application of microwave fields can cause polar side-chains of macromolecules to align with the direction of the electric field, possibly leading to the breakage of hydrogen bonds and alteration of the hydration zone. The principal factors of microwave irradiation that affect dielectric materials include temperature, radiation time, and penetration depth [9].

Currently, there is little information about the anaerobic treatability of microwaved sludge in continuous systems. Numerous studies have investigated the effect of pretreatments on the anaerobic digestion of sludge, but most of them have focused on the investigation of pretreatment using one type of sludge, whereas in most municipal treatment plants primary and secondary sludge streams are combined prior to anaerobic digestion [12]. Therefore, this study was conducted to investigate the effects of microwave irradiation on anaerobic digestion of a mixture of primary and secondary sludges by the semicontinuous flow mesophilic anaerobic digesters compared with thermal pretreatment.

\section{Materials and Methods}

\subsection{Sewage Sludge}

Primary and secondary sludges (Table 1) were obtained from a municipal wastewater treatment plant in Chuncheon, Korea and stored at $4{ }^{\circ} \mathrm{C}$ before use. The primary and secondary sludges were concentrated by gravity settling. Their total solid (TS) concentrations were 13.6 and $19.4 \mathrm{~g} / \mathrm{L}$, respectively. The high volatile solids (VS) to TS ratio in the sludges, $62-67 \%$, indicated that the sludges mainly consisted of organic substances. The low soluble chemical oxygen demand (SCOD) to total COD (TCOD)

Table 1. Characteristics of primary and secondary sludges

\begin{tabular}{lcc}
\hline \multirow{2}{*}{ Parameter } & \multicolumn{2}{c}{ Concentration (mg/L) } \\
\cline { 2 - 3 } & Primary sludge & Secondary sludge \\
\hline $\mathrm{pH}$ & $6.3 \pm 0.2$ & $6.5 \pm 0.2$ \\
$\mathrm{TS}$ & $13,653 \pm 264$ & $19,372 \pm 713$ \\
$\mathrm{VS}$ & $8,503 \pm 199$ & $13,050 \pm 704$ \\
VS/TS (\%) & $62 \pm 1.0$ & $67 \pm 1.3$ \\
TCOD & $12,855 \pm 577$ & $17,808 \pm 1,206$ \\
SCOD & $431 \pm 63$ & $520 \pm 141$ \\
SCOD/TCOD (\%) & $3.4 \pm 0.5$ & $2.9 \pm 0.8$ \\
NH ${ }_{4}^{+}$-N & $118 \pm 5$ & $206 \pm 18$ \\
Alkalinity & $1,088 \pm 85$ & $1,350 \pm 57$ \\
Acetic acid & $110.8 \pm 23.1$ & $387.0 \pm 48.6$ \\
Propionic acid & $130.2 \pm 10.0$ & $279.8 \pm 4.2$ \\
Iso-butyric acid & not detected & $81.4 \pm 2.5$ \\
Butyric acid & not detected & $109.9 \pm 7.3$ \\
Iso-valeric acid & $60.7 \pm 1.7$ & $142.9 \pm 3.2$ \\
\hline
\end{tabular}

ratio, $2.9-3.4 \%$ (Table 1), indicated that most of the COD was associated with the solid phase rather than the soluble phase. In all wastewater treatment plants, the primary and secondary sludges are produced at the same time and can be pretreated in an anaerobic digester, so in this study the sludges were blended $(50: 50 \mathrm{v} / \mathrm{v})$ to analyze the effects of microwave pretreatment on the solubilization of mixed sludge.

\subsection{Thermal and Microwave Pretreatments}

To study the microwave effects on sewage sludge we used a Microwave Accelerated Reaction System (MARS; CEM Co., Mathews, NC, USA; 0 - 1,600 W power output; 2,450 MHz frequency; 102 atm maximum pressure; temperature range, 0 $330^{\circ} \mathrm{C}$ ) equipped with temperature and pressure sensors within the cavity and a turntable with pressure-sealed vessels (Omni) of $100 \mathrm{~mL}$ each. Vessels with a $16 \mathrm{~mm}$ radius were used because the penetration depth was $17 \mathrm{~mm}$ for primary and $11 \mathrm{~mm}$ for primary and secondary sludges [13]. A microwave pretreatment temperature of $80^{\circ} \mathrm{C}$ was selected because the greatest improvement in biogas production was observed at this temperature using biochemical methane potential (BMP) assays (data not shown). The time required for the sludge to be heated from 20 to $80^{\circ} \mathrm{C}$ by microwave was $4 \mathrm{~min}$ at $1,000 \mathrm{~W}$ output power (temperature-increase rate $=15^{\circ} \mathrm{C} / \mathrm{min}$ ). Temperature holding time was set at $5 \mathrm{~min}$. Samples $(70 \mathrm{~mL})$ of sewage sludge were pretreated in a vessel rotating on the turntable. For thermal pretreatment, $200 \mathrm{~mL}$ of sludge was pretreated in a $500 \mathrm{~mL}$ Erlenmeyer flask covered with household aluminum foil on a magnetic hot plate stirrer in a same conditions used for microwave pretreatment. The time required for the sludge to be heated from 20 to $80^{\circ} \mathrm{C}$ was also adjusted to $4 \mathrm{~min}$ for thermal pretreatment and the temperature holding time was maintained for $5 \mathrm{~min}$, similar to microwave pretreatment. After that, samples were removed from the heating source, cooled passively to room temperature, and then stored at $4{ }^{\circ} \mathrm{C}$ before being used in the following experiments.

\subsection{Anaerobic Digesters}

Wide-mouth Erlenmeyer flasks sealed with three-hole rubber stoppers were used as digesters. After sludge samples were added, they were purged with $\mathrm{N}_{2}$ gas to remove $\mathrm{O}_{2}$. The total liquid volumes were $4 \mathrm{~L}$ for all three digesters fed with raw (control), thermally pretreated (TM), and microwaved (MW) sludges. The reactors were seeded with $30 \%$ anaerobic sludge obtained from the anaerobic digester of a local municipal wastewater treatment plant in Chuncheon, Korea. Ports in the rubber stopper were used to collect biogas and to feed and withdraw sludge. Digesters were fed once each day. Tedlar bags were used for biogas collection. Biogas production was measured manu-

\begin{tabular}{cccc} 
HRT (day) & Flow rate $(\mathrm{mL} / \mathrm{d})$ & \multicolumn{2}{c}{ Anaerobic digester } \\
20 & 200 & Influent \\
15 & 267 & \\
10 & 400 & \\
7 & 571 & \\
5 & 800 & & \\
& & &
\end{tabular}

Fig. 1. Schematic diagram of semi-continuous digesters at different hydraulic retention times. 
ally using a syringe. All reactors were kept at $35^{\circ} \mathrm{C}$ in a water bath and started at a hydraulic retention time (HRT) of 20 days. Each digester was operated at a constant HRT until the fluctuation of effluent properties and biogas production was within $\pm 10 \%$. Thermal and microwave pretreatments were tested in semi-continuous reactors with the control at HRTs of 20, 15, 10, 7, and 5 days and at corresponding organic loading rates (OLR) of 0.54 , $0.71,1.02,1.36$, and $1.85 \mathrm{~g} \mathrm{VS} / \mathrm{L} \cdot \mathrm{d}$, respectively (Fig. 1). Reactors were operated for at least three HRTs before decreasing the HRT [14]. None of the digesters showed adaptation problems when OLR was increased (i.e., HRT reduced).

\subsection{Analytical Methods}

All analyses were duplicated, and the results given are mean values. Concentrations of volatile fatty acids (VFAs) were measured using a gas chromatograph (Model 7890A; Agilient Technologies, Palo Alto, CA, USA) equipped with an HP-Innowax capillary column (length $30 \mathrm{~m}$; ID $0.25 \mathrm{~mm}$; film thickness 0.25 $\mu \mathrm{m})$ and a flame ionization detector (FID). Helium was the carrier gas, with a flow rate of $1.1 \mathrm{~mL} / \mathrm{min}$ and a split ratio of 40:1. To quantify methane in the biogas, the same gas chromatograph with an Alltech column (length $3.6 \mathrm{~m}$; ID $3.2 \mathrm{~mm}$; film thickness $2.2 \mathrm{~mm}$ ) and a thermal conductivity detector (TCD) was used. Helium was the carrier gas at a flow rate of $20 \mathrm{~mL} / \mathrm{min}$ without a split. The COD, solids, $\mathrm{NH}_{4}-\mathrm{N}$ concentrations, and alkalinity were determined according to the procedures in Standard Methods [15]. The dewaterability of digested sludge was determined using capillary suction time (CST) according to the procedure in the CST operating user manual (Kemik Co., Seoul, Korea).

\section{Results and Discussion}

\subsection{Effect of Pretreatment on Sludge Disintegration}

The degree of solubilization of the substrate can be estimated from the SCOD/TCOD ratio. SCOD/TCOD values of thermally pretreated $(10.7 \pm 2.1 \%)$ and microwaved $(12.4 \pm 1.2 \%)$ sludges were 2.7 and 3.2 times higher than that of the control $(3.9 \pm$ $1.3 \%$ ), respectively (Table 2). Therefore, SCOD/ TCOD values in

Table 2. Characteristics of raw, thermally pretreated, and icrowaved sludges

\begin{tabular}{lccc}
\hline \multirow{2}{*}{ Parameter } & \multicolumn{3}{c}{ Concentration (mg/L) } \\
\cline { 2 - 4 } & Raw sludge & $\begin{array}{c}\text { Thermally pre- } \\
\text { treated sludge }\end{array}$ & $\begin{array}{c}\text { Microwaved } \\
\text { sludge }\end{array}$ \\
\hline TS & $15,651 \pm 801$ & $15,995 \pm 975$ & $15,801 \pm 945$ \\
VS & $10,015 \pm 642$ & $10,007 \pm 727$ & $10,030 \pm 455$ \\
TCOD & $12,072 \pm 1,251$ & $12,218 \pm 1,716$ & $12,304 \pm 1,426$ \\
SCOD & $466 \pm 148$ & $1,283 \pm 198$ & $1,518 \pm 197$ \\
SCOD/TCOD (\%) & $3.9 \pm 1.3$ & $10.7 \pm 2.1$ & $12.4 \pm 1.2$ \\
Acetic acid & $216 \pm 58$ & $237 \pm 41$ & $242 \pm 30$ \\
Propionic acid & $115 \pm 53$ & $132 \pm 50$ & $136 \pm 45$ \\
Iso-butyric acid & $57 \pm 7$ & $60 \pm 6$ & $58 \pm 6$ \\
Butyric acid & $63 \pm 4$ & $59 \pm 8$ & $64 \pm 5$ \\
Iso-valeric acid & $88 \pm 20$ & $91 \pm 22$ & $89 \pm 18$ \\
\hline
\end{tabular}

the pretreated sludge were significantly higher than that in the raw sludge $(\mathrm{p}<0.01)$ and the value in the microwaved sludge was significantly higher than that in the thermally pretreated sludge $(\mathrm{p}<0.01)$. These results indicate that sludge solubilization was greater under microwave irradiation than under thermal treatment, and confirm previously-reported significant solubilization effects of microwaves on sewage sludge $[2,8$, 16-22]. Microwave pretreatment may have non-thermal effects on sludge solubilization that can easily be substantiated [11]. However, Eskicioglu et al. [23] reported that SCOD/TCOD values were always higher after thermal pretreatment than after microwave pretreatment, and postulated that this difference was due to the extended duration of exposure required in conventional heating (23 and $80 \mathrm{~min}$ ) to achieve a given temperature (50 and $96^{\circ} \mathrm{C}$ ) compared with microwave exposure (1.5 and $5 \mathrm{~min}$ ).

\subsection{Effect of Pretreatments on Anaerobic Digestion of Sewage Sludge}

The optimum $\mathrm{pH}$ range for effective decomposition of organic matter and maximized methane production during anaerobic digestion is $6.7-7.4$. If the $\mathrm{pH}$ is lower than 6.3 or higher than 7.8 , operational efficiency of the digester decreases significantly [24]. In this study, pH had a range of 7.3 - 7.6 in all digesters at all HRTs. Therefore, the reactor operated stably without reducing or decreasing the $\mathrm{pH}$ (Table 3 ).

To ensure confidence in the long term stability and quality of the results, semi-continuous reactor operation was first started at the HRT of 20 days. After the first 49 days of operation at the 20 day HRT, the values of $\mathrm{pH}, \mathrm{VS}, \mathrm{COD}$, biogas production, methane content, and total VFA (TVFA) in all digesters were stable (within $\pm 10 \%$ ) and the system was considered to be in a steady state. Upon completion of each run, the HRT was progressively reduced to $15,10,7$, and 5 days.

The VS removal efficiencies in the control, TM, and MW at the 20 day HRT were $32.3 \pm 1.3,37.4 \pm 2.5$, and $39.8 \pm 2.0 \%$, respectively. The COD removal efficiencies were $38.1 \pm 1.8,47.9 \pm$ 1.6 , and $50.7 \pm 1.8 \%$. Therefore, at the 20 day HRT, reduction of VS and COD was greater in the MW and TM than in the control, and was greater in the MW than in the TM (Figs. 2 and 3). Al-

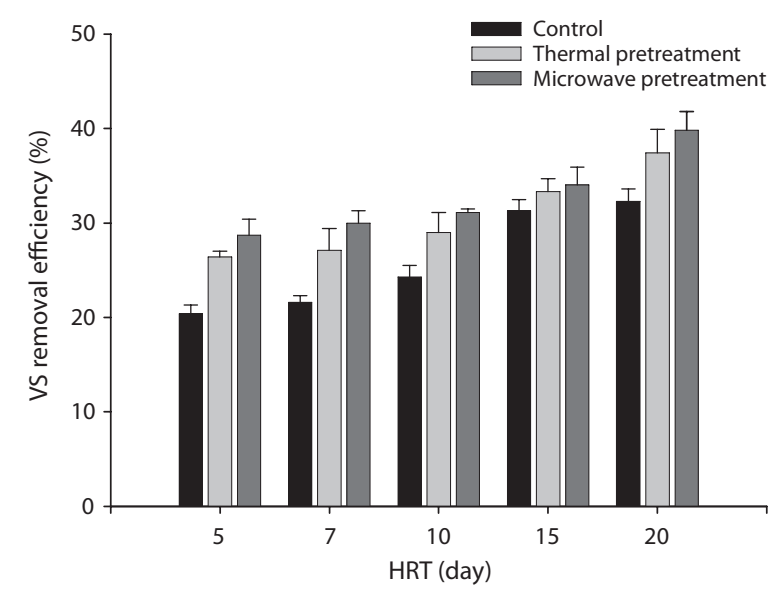

Fig. 2. Volatile solid removal efficiency of semi-continuous digesters fed with raw, thermally pretreated, and microwaved sludges at different hydraulic retention times. 


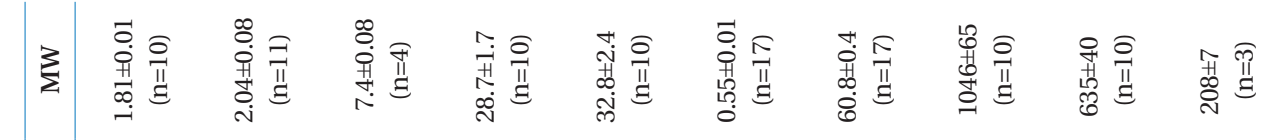

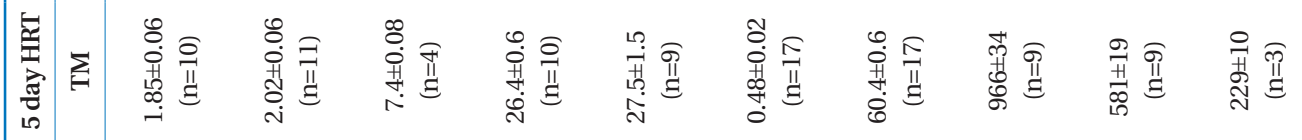

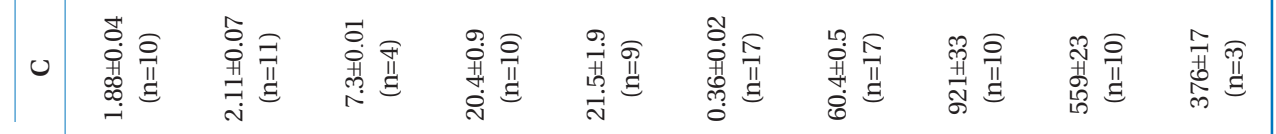

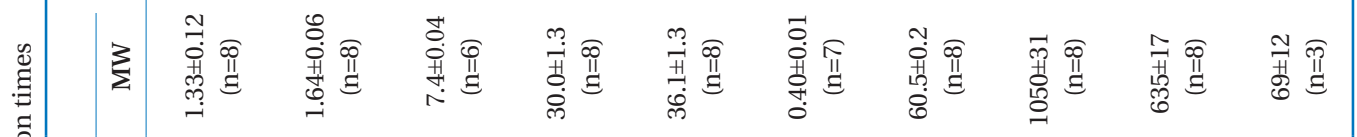

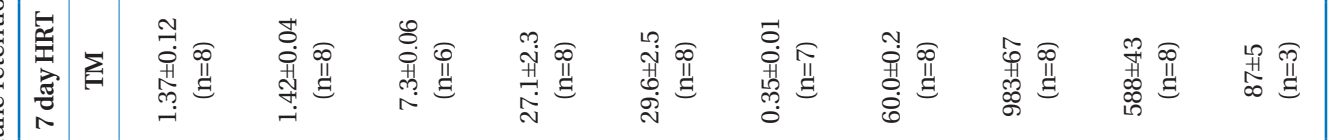

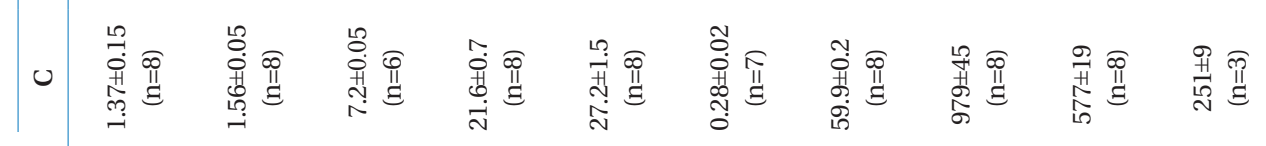

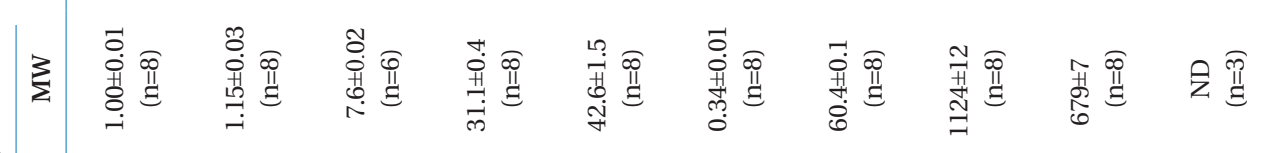

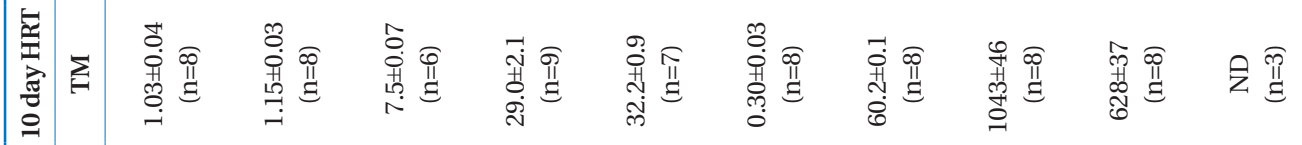

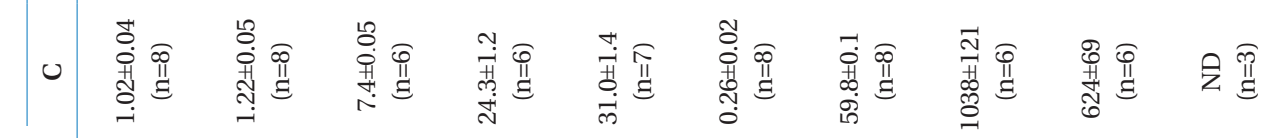

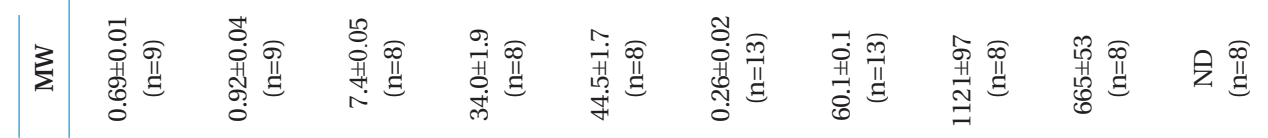

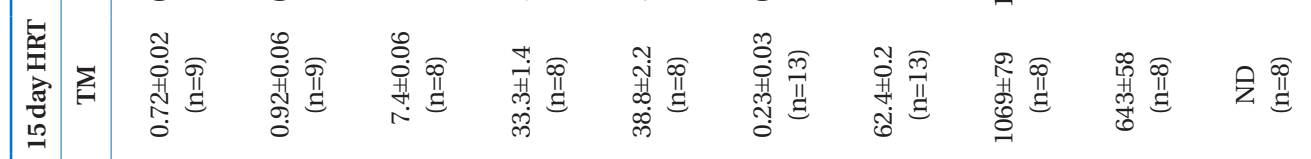

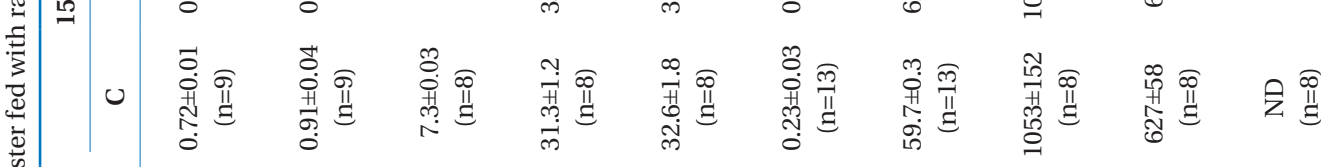

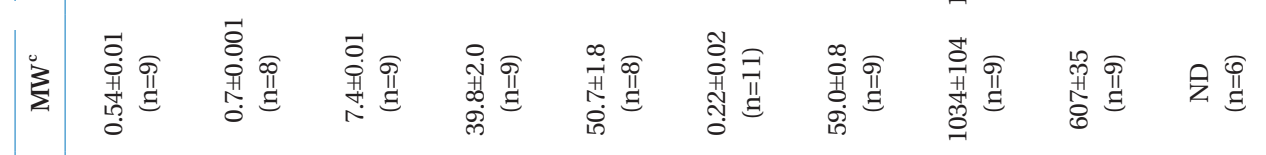

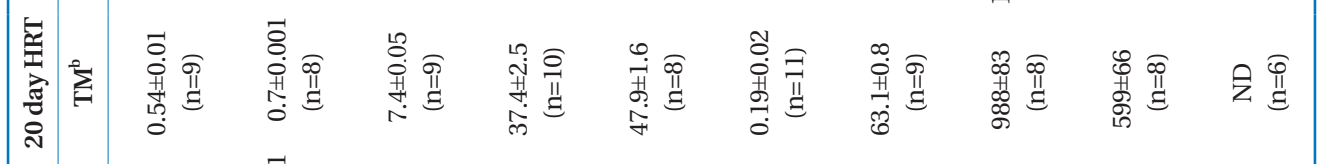
|

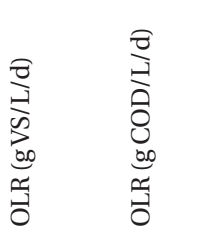

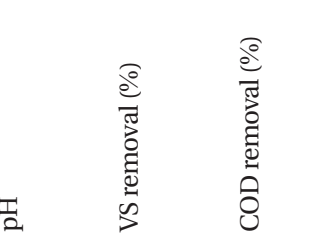
高咅

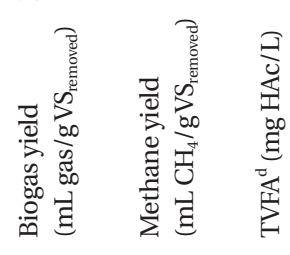

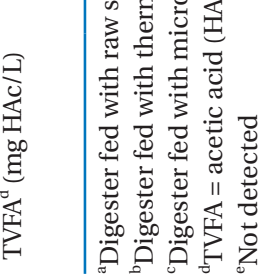


though VS removal of all digesters decreased when the HRT was reduced, the control performed less efficiently than the TM and MW [23]. Improvements in VS removal efficiencies of pretreated digesters relative to the control increased as HRT was reduced (Fig. 2). The greatest relative improvement in VS removals by both the TM and MW (29 and 41\% higher than the control, respectively) occurred at the HRT of 5 days. The results are logical, because pretreatments change the characteristics of the sludge and accelerate the hydrolysis step, but generally do not change the amount of degradable organic material in sewage sludge [23]. Improvements in COD removal efficiencies of the TM and MW, with respect to the control were 28 and $53 \%$ at the shortest HRT (5 days), respectively. These results indicate that the organic characteristics of untreated sludge at high OLRs limited the rate of organic matter degradation in the control [23]. Therefore, organic removal efficiency in the MW was always higher than that in the TM regardless of HRT. The VS and COD results were consistent with the hypothesis that reducing the HRT of the system causes an incremental increase of pretreatment effects

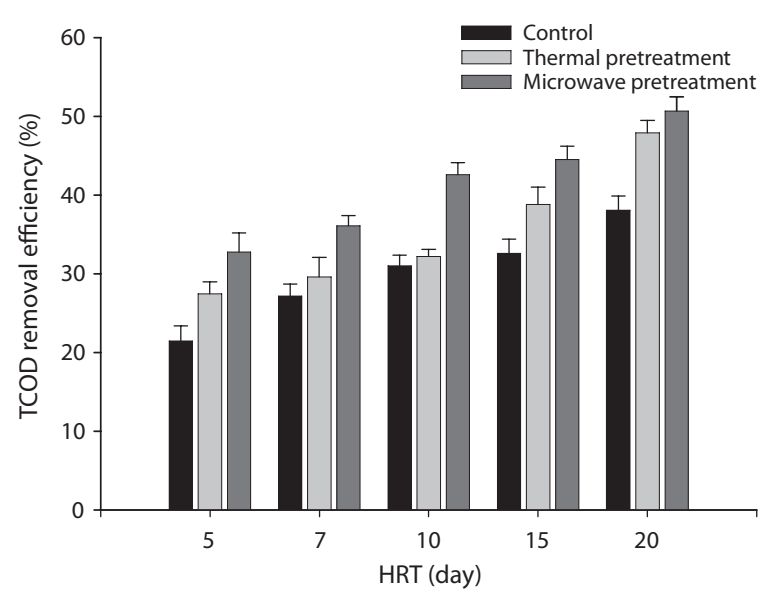

Fig. 3. Total chemical oxygen demand removal efficiency of semicontinuous digesters fed with raw, thermally pretreated, and microwaved sludges at different hydraulic retention times.

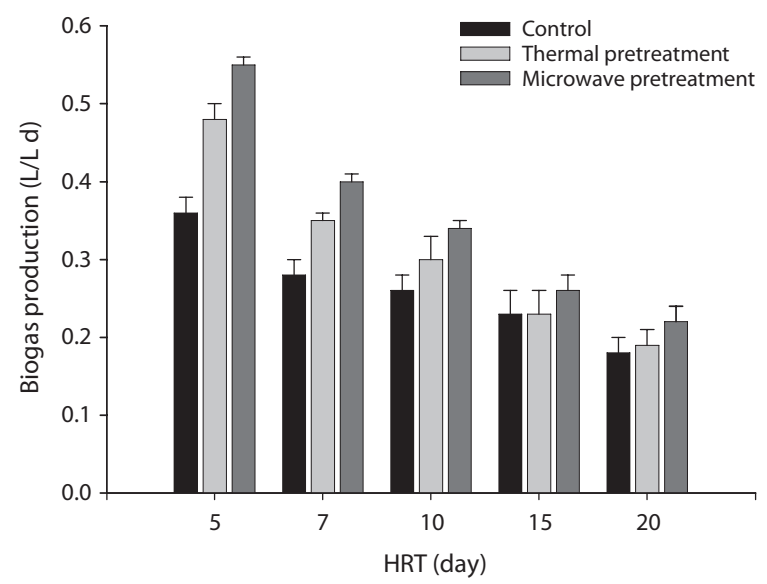

Fig. 4. Biogas production in semi-continuous digesters fed with raw, thermally pretreated, and microwaved sludges at different hydraulic retention times. when compared with the control [23].

As expected from the VS and COD removal efficiencies of digesters, improvements with thermal and microwave pretreatments in biogas production increased as the HRT was reduced to 5 days, except for the HRT of 15 days (Fig. 4) [23]. At the HRT of 5 days, the MW still converted organics into biogas more efficiently than other digesters and maintained the lowest VS, COD, and TVFA concentrations. These results indicate that the nonthermal effects of microwave irradiation increased the mesophilic anaerobic biodegradability of sewage sludge [8]. Organics inside the cells were released as a result of cell lysis by pretreatments, thereby increasing their biodegradability compared to that in the control sludge. Therefore, pretreated sludge became more susceptible to microbial attack, thus providing better substrates for methanogens and enhancing methane production [17].

The biogas results suggest that the pretreatments increased the amount of material available for biodegradation. Improvements in organic removal and biogas production at lower HRTs compared with the control are a strong indication that increased solubilization by thermal and microwave pretreatments converted a portion of the materials that are more difficult to biodegrade and increased the amount of materials that are more readily biodegradable. In all digesters, methane production increased with OLR if the efficiency of VS removal was maintained above a certain level (Table 3 ).

Unlike other process variables, the methane content of the produced biogas was in the typical methane content range of $58-63 \%$ [25] for all digesters regardless of HRT (Table 3). Methane yield had a range of $559-679 \mathrm{~mL} / \mathrm{g} \mathrm{VS}_{\text {removed }}$ in all digesters regardless of the HRT (Table 3). This is more than twice the value of $242-315 \mathrm{~mL} / \mathrm{g} \mathrm{VS}_{\text {removed }}$ determined by a BMP test in a study on the improvement of the anaerobic digestion efficiency of secondary sewage sludge using microwaves [17]. This difference might be partly because primary sludge was mixed with secondary sludge for a substrate in this study. Methane yields from mesophilic digesters in this study were within the range $(490-750$ $\mathrm{mL} \mathrm{CH}_{4} / \mathrm{g} \mathrm{VS}_{\text {removed }}$ ), determined by other pretreatment studies [26].

We compared three studies $[2,17,23]$ that evaluated the effect of microwave pretreatment of sewage sludge on the continuous performance of mesophilic anaerobic digestion. Two [17, 23] were conducted at microwave pretreatment temperatures below the boiling point of sludge. In one [23], daily biogas production increased less than $5 \%$ in the MW at 20 and 10 day HRTs. More significant improvements in biogas production compared to control were observed when the HRT was decreased to 5 days ( 15 and $25 \%$ for microwaved sludge at 50 and $96^{\circ} \mathrm{C}$, respectively) [2]. Park et al. [17] reported more promising results. At 15 and 10 day HRTs, the digestion of sludge pretreated by microwaves produced 24 and $36 \%$ more daily biogas than control, respectively. In one evaluation of semi-continuous mesophilic anaerobic sludge digestion after high temperature $\left(175^{\circ} \mathrm{C}\right)$ microwave pretreatment [2], the relative improvements in daily biogas production at high $\left(3.75^{\circ} \mathrm{C} / \mathrm{min}\right)$ and low $\left(1.25^{\circ} \mathrm{C} / \mathrm{min}\right)$ microwave heating rates were 84 and $47 \%$ higher than control at 5 day HRT, respectively. In the present study the relative improvements in daily biogas production after low temperature $\left(80^{\circ} \mathrm{C}\right)$ microwave pretreatment compared to the control $(0.36 \pm 0.02 \mathrm{~L} / \mathrm{L} \cdot \mathrm{d})$ were $33 \%$ in the TM $(0.48 \pm 0.02 \mathrm{~L} / \mathrm{L} \cdot \mathrm{d})$ and $53 \%$ in the MW $(0.55 \pm 0.01$ $\mathrm{L} / \mathrm{L} \cdot \mathrm{d})$ at the 5 day HRT. This is the most promising result among low temperature microwave pretreatment studies. 
At 20, 15, and 10 day HRTs, TVFA was not detected, indicating that TVFA was rapidly consumed during digestion (Table 3). However, TVFA was detected in all reactors when the HRT was lower than 7 days. In all cases, the average TVFA concentration was less than $400 \mathrm{mg} / \mathrm{L}$ in all digesters. This result indicates that the digesters were more stressful when the HRT was lower than 7 days. TVFA concentrations were highest in the control at the 5 day HRT and lowest in the MW, which showed that the MW was under the lowest stress. While the VFAs remained higher at 7 and 5 day HRTs, the changes of methane yield were not significant (Table 3) because the yield was recovered after a few days [27].

Both digested sludges in the TM and MW increases the CST, indicating possible reduction in dewaterability of digested sludges (Fig. 5). Based on the CST data, no potential improvement in digested sludge dewaterability is anticipated in the present study. This result is consistent with the dewaterability result from a previous study of BMP assays treating sludge [19]. On the contrary, Eskicioglu et al. [20,23] reported enhanced dewaterability of sludges coming from the MW. In general, in the present study dewaterability results of the sludge after TM were better than those of sludge after MW for all five HRTs [23].

\section{Conclusions}

This study evaluated the effects of thermal and microwave pretreatments on the digestibility of sewage sludge. SCOD/ TCOD values in the pretreated sludge were significantly higher than that in the raw sludge and the value in the microwaved sludge was higher than that in thermally pretreated sludge. The results of the digester operation also showed improved biogas production in the MW over the TM. At the HRT of 5 days, the MW still converted organics into biogas more efficiently than the other digesters and maintained lower VS, COD, and TVFA concentrations. These results suggest that microwave pretreatment is a more effective method of enhancing the solubilization degree and mesophilic anaerobic biodegradability of sewage sludge than thermal pretreatment. These results suggest that the non-thermal effects of microwave irradiation increased degradation of bacterial materials that commonly withstand direct anaerobic degradation.

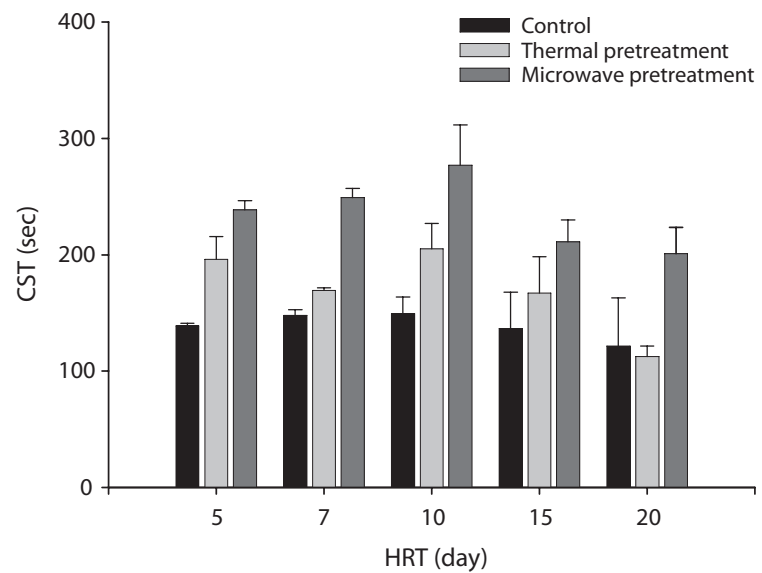

Fig. 5. Dewaterability data for digested sludge of semi-continuous digesters fed with raw, thermally pretreated, and microwaved sludges at different hydraulic retention times.

\section{Acknowledgements}

This research was supported in part by the Korean Institute of Environmental Science and Technology (EcoTechnopia-21 project), and the Ministry of Education, Science Technology (MEST) and National Research Foundation of Korea (NRF) through the Human Resource Training Project for Regional Innovation.

\section{References}

1. Weemaes MPJ, Verstraete WH. Evaluation of current wet sludge disintegration techniques. J. Chem. Technol. Biotechnol. 1998;73:83-92.

2. Toreci I, Kennedy KJ, Droste RL. Evaluation of continuous mesophilic anaerobic sludge digestion after high temperature microwave pretreatment. Water Res. 2009;43:1273-1284.

3. Rulkens W. Sewage sludge as a biomass resource for the production of energy: overview and assessment of the various options. Energy Fuels 2008;22:9-15.

4. Tiehm A, Nickel K, Zellhorn M, Neis U. Ultrasonic waste activated sludge disintegration for improving anaerobic stabilization. Water Res. 2001;35:2003-2009.

5. Salsabil MR, Prorot A, Casellas M, Dagot C. Pre-treatment of activated sludge: effect of sonication on aerobic and anaerobic digestibility. Chem. Eng. J. 2009;148:327-335.

6. Tanaka S, Kobayashi T, Kamiyama KI, Signey Bildan MLN. Effects of thermochemical pretreatment on the anaerobic digestion of waste activated sludge. Water Sci. Technol. 1997;35:209-215.

7. Neyens E, Baeyens J. A review of thermal sludge pre-treatment processes to improve dewaterability. J. Hazard. Mater. 2003;98:51-67.

8. Eskicioglu C, Terzian N, Kennedy KJ, Droste RL, Hamoda M. Athermal microwave effects for enhancing digestibility of waste activated sludge. Water Res. 2007;41:2457-2466.

9. Hong SM, Park JK, Lee YO. Mechanisms of microwave irradiation involved in the destruction of fecal coliforms from biosolids. Water Res. 2004;38:1615-1625.

10. Jones DA, Lelyveld TP, Mavrofidis SD, Kingman SW, Miles NJ. Microwave heating applications in environmental engineering-a review. Resour. Conservat. Recycl. 2002;34:75-90.

11. Woo IS, Rhee IK, Park HD. Differential damage in bacterial cells by microwave radiation on the basis of cell wall structure. Appl. Environ. Microbiol. 2000;66:2243-2247.

12. Gavala HN, Yenal U, Skiadas IV, Westermann P, Ahring BK. Mesophilic and thermophilic anaerobic digestion of primary and secondary sludge. Effect of pre-treatment at elevated temperature. Water Res. 2003;37:4561-4572.

13. Hong SM, Park JK, Teeradej N, Lee YO, Cho YK, Park CH. Pretreatment of sludge with microwaves for pathogen destruction and improved anaerobic digestion performance. Water Environ. Res. 2006;78:76-83.

14. Valo A, Carrère H, Delgenès JP. Thermal, chemical and thermo-chemical pre-treatment of waste activated sludge for anaerobic digestion. J. Chem. Technol. Biotechnol. 2004;79:1197-1203.

15. Eaton AD, Franson MAH, American Public Health Association, American Water Works Association, Water Environment Federation. Standard methods for the examination of water and wastewater. 21st ed. Washington, DC: American Public Health Association; 2005. 
16. Hong SM. Enhancement of pathogen destruction and anaerobic digestibility using microwaves [dissertation]. Madison, WI: University of Wisconsin-Madison; 2002.

17. Park B, Ahn JH, Kim J, Hwang S. Use of microwave pretreatment for enhanced anaerobiosis of secondary slugde. Water Sci. Technol. 2004;50:17-23.

18. Eskicioglu C, Kennedy KJ, Droste RL. Characterization of soluble organic matter of waste activated sludge before and after thermal pretreatment. Water Res. 2006;40:3725-3736.

19. Kennedy KJ, Thibault G, Droste RL. Microwave enhanced digestion of aerobic SBR sludge. Water SA 2007;33:261-270.

20. Eskicioglu C, Kennedy KJ, Droste RL. Enhancement of batch waste activated sludge digestion by microwave pretreatment. Water Environ. Res. 2007;79:2304-2317.

21. Eskicioglu C, Kennedy KJ, Droste RL. Initial examination of microwave pretreatment on primary, secondary and mixed sludges before and after anaerobic digestion. Water Sci. Technol. 2008;57:311-317.
22. Eskicioglu C, Prorot A, Marin J, Droste RL, Kennedy KJ. Synergetic pretreatment of sewage sludge by microwave irradiation in presence of $\mathrm{H}_{2} \mathrm{O}_{2}$ for enhanced anaerobic digestion. Water Res. 2008;42:4674-4682.

23. Eskicioglu C, Droste RL, Kennedy KJ. Performance of anaerobic waste activated sludge digesters after microwave pretreatment. Water Environ. Res. 2007;79:2265-2273.

24. Lay JJ, Li YY, Noike T, Endo J, Ishimoto S. Analysis of environmental factors affecting methane production from highsolids organic waste. Water Sci. Technol. 1997;36:493-500.

25. Wood N, Tran H, Master E. Pretreatment of pulp mill secondary sludge for high-rate anaerobic conversion to biogas. Bioresour. Technol. 2009;100:5729-5735.

26. Parkin G, Owen WF. Fundamentals of anaerobic digestion of wastewater sludges. J. Environ. Eng. 1986;112:867-920.

27. Ahring BK, Sandberg M, Angelidaki I. Volatile fatty acids as indicators of process imbalance in anaerobic digestors. Appl. Microbiol. Biotechnol. 1995;43:559-565. 